\title{
Functioning and Development of Retail Banking in Russia
}

\section{Lyudmila I. Chernikova}

\begin{abstract}
Doctor of Economics, Professor of the Department "Corporate Finances" of Financial University under the
\end{abstract} Government of the Russian Federation, Email: tariff2004@mail.ru

\section{Guzel R. Faizova}

Ph.D. in Economics, main economist of "Scientific enterprise "Proekt-Avromatika" LLC Email: guzel_faizova@mail.ru

\section{Elena N. Egorova}

Ph.D. in Economics, Docent of the Chair of Accounting and Finances of Moscow Institute of State and Corporate Management, Email: egelni@yandex.ru

\section{Natalya V. Kozhevnikova}

Ph.D. in Economics, Docent of the Chair of Economical and Mathematical Sciences of Non-State Educational Establishment of Higher Professional Education “University of Management "TISBI", Email: kogevnikovaN@yandex.ru

\section{Doi:10.5901/mjss.2015.v6n6s4p274}

\section{Abstract}

The article shows the results of research of functioning and development of retail banking in Russia. The article views topical issues related to specifics of this segment of banking sector. Experience in retail business allows banks to develop goods and services which are in highest demand by population and have a huge social importance, which is the basis for the study of the role of banking services as a social component. Successful development of retail banking requires constant perfection of channels of promotion and distribution of products and services, which leads to emergence of automatized offices of selfservice and online bank offices in the Internet. The notion of infrastructure of retail banking is revealed, which should be understood as synergy of classical infrastructure and virtual implementation of the processes of realization and promotion of goods and services. The article views the models of evaluation and forecast of credit risk and shows principle of managing the retail credit risk, which are the foundation of the organization of system of retail credit risk management. The authors formulate the priorities of development of the system of management of retail credit risk. The conclusions substantiate that active development of retail banking is accompanied with high risks and high level of competition in the market of banking services, which leads to necessity for constant search for actual and effective solutions in the sphere of organization and development of retail banking.

Keywords: retail banking, retail banking services, bank, bank risks, infrastructure.

\section{Introduction}

Under the conditions of tough competition in banking sector and development of technologies and approaches to managing business processes, retail banking is a key direction of activities of credit organizations. Good work of retail direction is one of the most important goals of banks.

Due to natural aging of the Russian population within the framework of general education and financial literacy, its needs grow together with growing requirements to the quality of provided banking services.

Success of development of retail banking depends not only from development of technologies, growth of demand for banking products and services, but also on the capabilities of banks to effectively integrate external solutions into internal business processes for the purpose of efficient realization of product or service.

Retail banking is one of the most important directions in functioning of dominating number of credit organizations, which can be a significant source for attracting resources and a perspective variant for placement of assets by banks for the purpose of receiving high financial result. At present, retail business is one of the main growth factors of banking 
sector and a key segment of activities of the most banks. The share of retail sector in banking sphere will grow with growth of prosperity of the Russians and their having higher needs for credit, payment, investment, and other financial services (Zaernyuk, Faizova, 2012).

Development of retail banking consists in improvement of the quality of provided products and services to population, search for new solutions as to emerging needs of clients, development of applied informational technologies and software products, and perfection of the systems of evaluation and management of retail risks.

The purpose of the conducted research is determination of the most important aspects of functioning and development of modern state of Russian retail banking business through: determination of its specifics and role; viewing it as a social component; study, discovery, and formation of the notion of infrastructure of retail banking; study of existing models of evaluation and forecast of credit risk and determination of principles of retail credit risk management.

\section{Specifics of Retail Banking}

A new stage in the development of retail banking services is the increase of the role of specialization of activities of retail banks as to their cooperation with husbandries and between themselves. Retail banks are to go through the stage of specialization in the market of retail banking services both in system and in intra-system, and inter-system relations, i.e., systemic specialization of activities. Thus, systemic specialization of activities of retail banks is the form of organization of work of retail banks in the market of retail banking services as a system based on the simultaneous concentration of activities at servicing certain groups of husbandries and production, sale of retail banking services, or conduct of payments of husbandries for goods and services (Trofimov, 2013).

As a matter of fact, retail bank cannot refuse from servicing corporate clients. In practice, conduct of such service, as, for example, "payroll card program", could be hindered by lack of possibility to open enterprise's account with a bank. Actually, the organization can transfer the money within the payroll card program to bank cards of employees from other credit organizations, but the client may have a wish to open another account with the bank for the purpose of convenience in payments. Also, with the development of bank card business, retail bank can develop the service of acquiring, which also may lead to organization wishing to open an operating account with the bank that will conduct acquiring (Krestovskiy, 2010).

One of the most noticeable and vivid specifics of retail banking is the fact that its significant part is represented and conducted through standardized processes of servicing and provision of standard products and services. This feature is a decisive factor of growth and increase of profitability of retail banking under the modern conditions. Retail banking operations are based on the offer of standardized products. Development and implementation of standard conditions of provision of banking services to clients is a necessary condition for successful development of retail banking due to its mass focus. Standardized products include products of consumer crediting, express-credits, payment cards, deposits, payment operations, etc.

Presence of clearly formulated standardized processes of servicing and products will allow - if necessary performing a mobile change according to new demands of clients, which will allow compensating the impossibility of provision of individual servicing for all clients of the bank (Faizova, 2013).

A specific feature of retail banking is the fact that all conditions for provision of products of this direction, including their cost, are published openly on banks' web-pages and information \& analytical portals (regarding interest rates for deposits and loans). Unlike, for example, the format of publishing data on products and services, offered to corporate clients, which, for example, require individual confirmation.

It should be noted that new interesting deposit products appeared in the market of banking services recently, including the so called combined deposits. Generalizing the existing ideas of this new product, it is possible to say that combined deposit is a bank product which combines the combination of traditional banking and investment \& financial tools, depending on certain market indicators. As a rule, general structure of combined deposit is standard and consists of two parts - guaranteed and non-guaranteed. In other words, the product combines the deposit with fixed profitability i.e., as a rule, more profitable financial tool. Another peculiarity of combined deposits is a possibility for creation of products for specific clients' needs (Zaernyuk, Faizova, 2012).

Together with expansion of product line and focus at development and implementation of innovational products, an important role in the retail segment of banking business belongs to modern solution which ensures automatization of all stages of client servicing, facilitating the increase of the quality of business processes and improvement of client service. High level of automatization, certainly, influences the quality and speed of client service. Technological solutions stipulate the development of product line of the bank, increasing the attractiveness of the offered services (Faizova, 2013).

All components of informational system of retail bank (automatized banking system, fully functional processing 
system, specialized functional products) should have the following criteria: speed, scalability, and high adaptability (Demidov, Goryunov, etc., 2004).

Thus, a necessary condition for building effective system of retail banking business is presence of clearly formulated and unique standardized processes of services and products through high level of automatization, open offer of products and services, and regional expansion.

\section{Social Component of the Market of Retail Banking Services}

The retail banking segment has a peculiar and vivid direction - satisfaction of private social needs.

Experience in retail business allows the banks to develop products and services which are most required by population and have a huge social significance, including housing credit, transfer of family capital and welfare to bank cards or current cards, open with bank, and pension servicing. Feedback effect allows improving conditions of business conduct, thus stipulating just distribution of material benefits in society. Preservation of accessibility of banking services is an important factor of corporate social responsibility for most commercial banks. At that, a systemic factor of the market of retail banking services is performing the following functions:

1) formation and redistribution of assets of individuals. Here an important thing is wide idea of social components of banking services market, at which banking activities are connected to manufacture of services of special kind, the most important of which is provision of economic revenue by payment means;

2) conduct of payments for goods and services consumed by individuals. Here an important idea is narrow social component of the banking services market, at which banking activities are connected to participation in satisfying social needs of citizens and realization of social policy of state.

Systemic factors of retail banking services market are shown in Fig. 1.

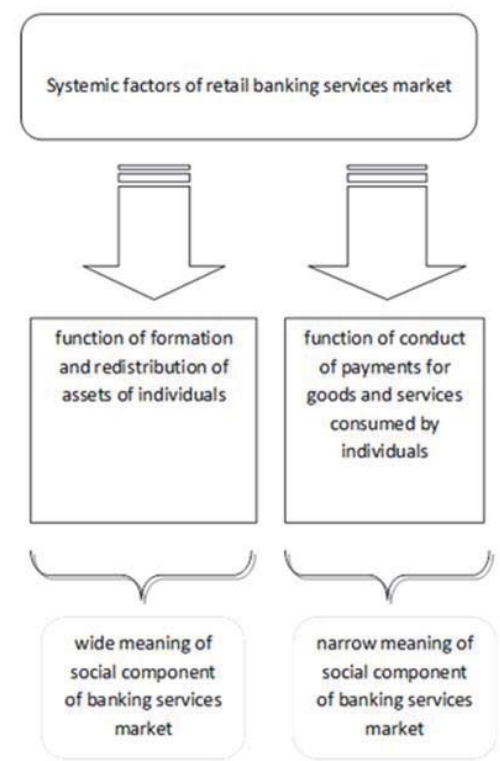

Figure 1. Systemic factors of the retail banking services market

Thus, the role of banks in modern economy has not only financial \& economic, but social component which should stipulate the implementation of bank's potential, satisfaction of needs for participation in social changes and being in demand through provision of possibility for implementing own social projects. Moreover, many tools of economic policy, used by the state for financial \& credit support for top-priority sectors of economy, are directly connected to activities of commercial banks and change of the system of projects financing, included into state programs. These include the following (Silaeva, 2012): 
1) use of financial tools for stimulation of development of housing market, especially - increase of accessibility of housing for population through mechanism of mortgage housing credit (certain categories of population can become members of special mortgage programs: mortgages for young families, military mortgage, social mortgage).

2) support for business activities due to development of crediting of small and medium business in regions with complex socio-economic situation;

3) creation of possibilities for the increase of quality of life of population with the use of mechanism of consumer crediting;

4) creating possibilities for elimination of existing social inequality and the increase of financial, socio-cultural, and educational level through the use of educational loans;

5) increase of general accessibility of credit products on the whole by means of subsidizing interest rates for loans.

Thus, commercial banks are oriented at different groups of society and have a possibility to offer their services to the retired and to the well-to-do citizens. At that, modern commercial banks proceed on the basis that there is a necessity to work individually with each client: any banking service is rather difficult for understanding. For example, during the issue of plastic cards, bank consultants tell each employee what advantages they will acquire from cashless transfers. Supposing, not everyone knows that it is possible to use this card to pay for goods and services at selling spots with discounts, or even pay for mobile service by simply sending a SMS.

It should be noted that accessibility of financial products and services in Russia is at a relatively low level. On the one hand, share of able-bodied population, covered by various credit, card, and deposit programs and services, is rather high and constitutes $77 \%$ (for insurance products this indicator is lower - 57\%). At the same time, usage of these products is not active: the services, registration of which is set by the law or third parties, are the most popular with consumers.

One of the most significant barriers for using financial services is the level of trust to their suppliers: the most trusted are banks (74\% of Russians trust them), while this indicator for other market players - insurance and investment companies, micro-financial organizations is much lower (44\%,21\%, and 14\%, correspondingly). Primarily, such indicators can be explained by low awareness of population regarding activities of such organizations and uncertainty for possibility of protection of their rights in case of certain problems.

Taking into account actuality of mortgage, banks offer their own programs. At that, commercial banks offer several specialized and basic programs which are developed for making mortgage accessible for various groups of population and providing all applicants with housing.

At present, Russian commercial banks offer basic mortgage programs with attractive conditions for crediting. Except for basic programs, there are special mortgage terms for certain categories of clients. They cover not only young families but large families and the retired. Each program and each specific case has its own terms. Purchase of housing for young family supposes one program, while improvement of housing conditions supposes another program. It is not difficult to choose the most optimal program.

Thus, recently another important socially-oriented direction of development of banking services became the so called social mortgage. At present, the program, of social mortgage offers several variants:

1) selling state housing in mortgage for reduced price;

2) subsidizing interest rate for mortgage;

3) providing subsidies for a part of cost of mortgage housing.

Social mortgage is mortgage programs which provide social groups of population additional possibilities for purchase of housing. Social mortgages are accessible due to reduced rates, accounting of subsidies, and lower cost of housing. This direction of activities is a landmark of strategic development of agency which supposes development of special mortgage programs for certain categories of population (social mortgage); financing infrastructure during construction of economy class housing; development of rent accommodation market; further development of the market of mortgage securities. At present, social mortgage is involved with re-financing of mortgage, issued by banks according to its standards. It was well-reasoned at the stage of emergence of the market of mortgage crediting, but now, when mortgage loans are issued actively, the share of social mortgage in the mortgage market is low (8.2\%), and actuality and necessity for further work of agency from the point of view of institute of development disappears.

Thus, in financial sphere, many commercial, banks see their task in creation and promotion of required banking products with important social component. When banking business takes into account principles of social business, it allows solving social problems and achieving stable results. Socially oriented banking business is more innovational, has more credibility from clients, and should develop in equal conditions for conduct of business for all banks, regardless of the fact which form of ownership and level of state participation they have. 


\section{Infrastructure of Retail Banking}

Successful development of retail banking requires constant improvement of channels of promotion and distribution of products and services, which leads to emergence of automatized offices of self-service and online offices of banks in the Internet.

Development of retail business sets before banks the task of building effective system of management of promotion of retail products. Very often, the banks face the situation when system of cooperation of main office of bank and its branches for retail products sale is not properly built, employees do not have the required experience of retail development, management of branches has a very passive position regarding issues of retail business development, functional responsibilities of employees of retail block in branches are not distributes, and, as a consequence, usage of employees in branches and additional offices for retail business is performed only for 30-50\% (Kardashov, 2007).

The need for study of infrastructure of various spheres of economy acquires special actuality under the modern conditions, which are characterized by substantial expansion and complexity of economic ties. Formation and development of sectorial infrastructure which corresponds to modern market are the least development directions in modern research. This condition relates also to banking sphere and infrastructural provision of activities of credit organizations. Banking services market infrastructure is peculiar for characteristics of generic term of infrastructure, as well as specific features, which are caused, firstly, by peculiarities of main activities - banking, and, secondly, by specific features of banking market of Russia at the modern stage of its development.

The study of Soviet economic literature didn't reveal a single mentioning of the notion of "banking infrastructure", let alone the term "infrastructure of banking services market". This is true for educational, monographic, and encyclopedic literature. For a long time, infrastructure in economic studies was viewed as something secondary and additional. Accordingly, studies of infrastructure had additional and secondary nature (Semenyuta, Amichba, 2011).

Infrastructure of retail banking is a synergy of classical infrastructure (network of ATMs, additional offices, branches, cash desks, regional offices, and offices of self-service) and virtual implementation of processes of realization and promotion of products and services.

Thus, economic dictionary defines market infrastructure as establishments, forms, and companies of all types of ownership, which provide cooperation between subjects of market relations (Azriliyan, 2007). Business infrastructure is surroundings of business subjects, activities of which stipulate each businessman's performing professional functions and tasks regarding conducts of their activities (Rubin, 2007). Finally, retail is product sold or purchased apiece or in little numbers (Azriliyan, 2007). Thus, infrastructure of retail banking is total surroundings of the subjects of financial entrepreneurship, activities of which stipulate provision of financial services by entrepreneur, in part of provision of retail banking services.

An important element of infrastructure of banking activities is institutes of credit histories, which are based on the principle, according to which creditors (banks, financial companies, companies which emit credit cards, investment companies, trading companies which issue commercial loans) constantly exchange information on borrowers' paying capacity. Development of modern institutes of credit market infrastructure, one of which is loan office, allows minimizing risks which accompany this process (Kocharyan, 2009).

Retail banks often face new tasks due to globalization, expansion of markets, toughening of norms and laws, growth of the level of client demands, and increase of competition. Besides, while 20 years ago the assortment of average retail bank included 3-6 products, today it consists of 300-500 products. A while ago, typical bank included three departments (for work with individuals, corporate clients, and small and medium business), and modern banks often have 25 and more departments for various market segments.

These problems concern all banking products, including mortgage, consumer credits, credit cards, quick deposits, and demand deposits. Growth of the volume of transactions requires the adequate level of effectiveness of operations, while inherited technologies, based on traditional products and isolated systems, very often cannot provide this level. Due to fragmentation of business systems and data, many banks simply do not have flexibility, necessary for adapting to changing requirements and conditions of business. Another problem (and additional possibility) consists in reconstruction of channels of work with clients for stimulation of growth of retail banking business: consumers gladly switch to channels that are alternative to traditional "paper" ones. IT-systems which provide the necessary information in time give banks the possibility to expand business without increasing the staff.

New technologies will help the banks to keep up with the times. At present, IT infrastructure of banks - instead of planned development - has to quickly react to changes of business requirements, territorial growth, and changes in banking laws. As a result, there emerge infrastructures, comprised of various inherited IT systems and applications, scattered databases of business information which copy the client data and give fragmented idea of their needs. 
Fragmented information from unrelated IT systems gives incomplete idea of a client. Due to that, sales are performed "manually", operations remain fragmented, cooperation with clients suffers, and clients' satisfaction reduces. Retail banks can preserve competitiveness only if they use modern business tactics for search, attraction, and preservation of clients. Banks also have to search for ways for the increase of effectiveness of staff work, satisfaction of clients, and profitability.

Retail banks have to quickly adapt to changing conditions of the market and business requirements and search for additional ways of gaining profit and increasing the work efficiency. All retail banks require constant changes according to the results of analysis of the market and clients' needs: redistribution of resources, optimization of business processes, and management of financial products assortment.

Strategies of retail banks in the part of improvement of client services, management of work channels, and increase of effectiveness of risk management and main operations are based on the knowledge of the client image and their preferred ways of cooperation with bank. Foundation of banking business under the terms of partnership with client - accumulation of required information on client and use of this information for business analysis and development of criteria of consumer value. Banks need to support the transparency of operations for effective joint work of internal departments: it is necessary in order to free agents from solving technical issues and create with the clients the image of cooperation with one organizations which helps them with financial tasks.

Probably, everyone has faced a situation when, while in a bank contact center, a client has to tell his problem repeatedly to several agents. For each explanation, agents spend several seconds to entering account and card numbers and other basic data in various systems, which leads to millions of losses annually. When information exchange is not elaborated between systems that support retail services, operations in branches, and business analysis, total volume of lost opportunities is really astonishing.

The path towards transparency of operations starts from modernization of IT infrastructure - perfection of organization and turning it into system, oriented at client.

Quantitative indicators of consumer value and adequate division of market into segments have a key meaning for retail banks which strive to provide their clients with products and services of the highest quality. These are foundations, without which the bank cannot work effectively and show stable growth of business and volume of profit. Only a few banks have realized the full potential of the use of indicators of consumer value in the model of development and as a basis for development of business strategies. That's why there is growing interest to CRM-systems that provide retail banking with the following means:

Profiling of clients and diversification of strategies of work with clients. CRM-systems allow bank employees to gather information with each cooperation with client, so with time they could form deeper understanding of their needs and build a strategy of work with them. This knowledge allows personal managers to forecast changes of client's needs and market situation on the whole, in order to timely offer products and services to client, save time, and increase competitiveness.

Advertising campaigns management. Means of CRM-systems will allow marketing departments to divide the market into segments and manage marketing lists. The possibility for quantitative and qualitative evaluation of campaign results provides the maximal feedback for all cooperation channels and growth of the number of potential clients.

Business analysis. Means for organization of databases and analysis of accumulated information provide topmanagers with complete information on clients and the data required for planning and development of successful strategies which increase profitability of business and return on investments.

Business processes management. Means of automatization and management of technological and business processes help banks to register complete information on interested clients and possibilities, determine quotas of selling departments, support the fulfillment of personal plans and tasks of employees, and minimize paper documentation turnover.

Consolidated client data base and full report on products and services that are used by each client. Consolidation helps to unify the offered services and increase the effectiveness of joint work of departments, achieving higher satisfaction of clients and preservation of client base.

Banks that support single standards of client service standards through any channels, build and preserve the most trustworthy relations with clients. CRM-system in such banks provides collection of information on any cooperation with clients regardless of the channel, and the bank has a possibility to use the collected data during the work with client through any channels. Thus, the agent that contacts a client personally or by phone can receive data that was entered by the client during applying for a loan via the Internet.

Bank community knows that expansion of channels of work and client-oriented approach are a powerful basis for the increase of the level of client service and development of effective business strategies. Implementation of CRM- 
system in retail banking business increases consumer value of banking and products by means of effective use of information on client regardless of the selected channel of cooperation with bank.

Banks need new informational systems which are able to perform the tasks of several departments, thus providing high level of accessibility, integration, simplicity, and possibilities for reporting and analysis. While the process of sales is structured well in many banks, the corresponding IT-systems do not ensure the required level of flexibility that is required for constant improvement of business processes.

Successful implementation of CRM-system that will allow guaranteeing the solution of long-term tasks and protection of investments, the bank will have to build long-term partnership with suppliers of IT-solutions. The supplier has not only to focus the required amount of efforts and resources for initial implementation, but also to provide technical support for CRM-solution after that. An appropriate supplier is the one that:

1) orients at long-term partnership and has a clear plan of activities that covers implementation, constant support, and modernization of CRM-solution, as well as provision of growth of partnership and client network of the bank;

2) ensures the bank employees' readiness for independent work with implemented system and help the bank to receive independence in the use of CRM-solution;

3) conducts regular training of clients and partners with novelties of IT-system after its modernization, simplifying the transition to new versions of applications and saving customer's time;

4) offers solutions on the basis of popular platforms and infrastructures, allowing the bank to choose partners freely for implementation and support for IT-solution.

Bank has to develop formal criteria for evaluation of profitability and total cost of owning the new IT-system, while partner has to offer the plan of implementation which ensures the achievement of goals set by the bank. Formulation of the goals of implementation should include the supposed number of simultaneously working users, bank accounts, clients, volume and types of transactions, and approximate value of necessary equipment and its support.

Partner has to offer equipment that is compatible with one of the independent standard platforms. It is also important for the supplier to take into account into recommended configuration of equipment the current load to IT-system and its further growth according to expected speed of growth of organization-customer. The offered IT-infrastructure should provide the growth of business through simple modernization of equipment, not requiring its global replacement. The offered solution should have the necessary level of constant accessibility and scalability, except for period of planned service and reserve copying.

The developed project should take into account the requirement of redundancy of IT-systems of main office by means of using cluster technologies, web-farms, reserve servers, and technologies of recovery, this effectively providing high level of access to IT-systems of bank with sensible financial expenses.

Retail banks realize the necessity for allocation, attraction, and preservation the most valuable clients, but very often do not have a full and comprehensive understanding of them.

Besides, demand for flexible service and bank products, which correspond to clients' needs and are accessible through various channels, equaled the chances in competitive struggle of banks. The banks need IT-systems that will allow employees of branches to come up with more effective solutuions and will provide them full image of clients' needs. This should facilitate closer cooperation of bank and client and open wide possibilities for implementation of additional financial services and products.

The ones responsible for decision making realize importance of this complex approach, but are not in a hurry to take decisive steps for its implementation. They are checked by fear of excessive expenses, misunderstanding of users, and long time required for start of CRM-systems which support the required functions.

\section{Priorities of Development of the System of Retail Credit Risks Management}

At present, one of the most important types of activities in retail banking is crediting. Firstly, credit operations are the most profitable for banks, but, at the same time, the riskiest - as even with corresponding provision, the effectiveness of a credit deal is unknown at the time of making a credit agreement. Secondly, crediting solves problems of citizen's satisfying their consumer needs, improves population's living standards, and provides housing, thus solving accommodation problems, which leads to expansion to total consumer demand which stipulates development of production and trade. The process of crediting is accompanied by risk of loan default (credit risk) which is one of the most important risks for credit organizations (Lukoyanova, Shibakov, 2011).

Right determination of the level of retail credit risk is a very difficult task, which cannot be solved without use of special methods of quantitative evaluation and corresponding mathematical apparatus. However, in most cases, during 
evaluation of credit risk, probability calculations are used as a methodological basis. Possibility of one or other risks events could be determined with the help of means of mathematical theory of probabilities.

Many players in the market of consumer crediting use improved means of modeling of credit risks. In order to use the data from the above sources in practice, it is necessary to apply significant corrections to people, technologies, and used approach. Three main directions of changes: human resources, informational technologies, and cooperation between specialists for evaluation of risks and marketing departments.

Human resources. Most likely, even the most successful managers will have to acquire new skills for development of the models of risk evaluation that would take into account possibilities of forecasting on the basis of existing data. Credit organizations will have to involve in this process the professional from different spheres, primarily - specialists in statistics which possess technical skills of analysis of variables which determine the value of risk. This might mean that it would be necessary to expand the staff in order to have more employees with Ph.D. - which are plenty in many banks. However, even the slight reduction in the level of losses will completely cover expenses for attraction of these specialists. If the credit organization didn't have employees of this level, the scale of profit will be much greater. Among other resources, which should be used by credit establishments, are experts in business spheres, from which the data comes, including, as an option, employees of partnership organizations. Specialists in marketing and managers from sales sector can share valuable information on buyers and invent new methods for usage of more detailed evaluation of risks for the increase of effectiveness of management of buyer's life cycle.

Informational technologies. Besides, credit organizations require more powerful computational tools. As a rule, the data of credit bureaus, including data on the usage of credit lines, violations, and applications for loans, are based on limited number of events, related to financial services. However, information from new sources, including the data of mobile operators, can include gigabytes of data - even for a small base of potential clients. There is a risk that during processing of such huge massifs of data, the software that is used by most financial organizations for statistical analysis, could stop coping with its tasks. Credit organizations will have to invest assets into purchase of more powerful computational equipment and corresponding software. Recent achievements in the sphere of cloud programming allow finding solution for more reasonable price that before that.

Cooperation between specialists for risk evaluation and marketing departments. Besides, credit organizations have to develop plan of actions for collection of data from non-traditional sources. Many work groups for evaluation of credit risks has been conducting similar activities for a couple of decades. They built a complete list of standard indicators, including calculation of growth rates or use of fictional variable for allocation of clients which have at least ones not paid the debt. Still, it one sees a table with 300 payments, 2,000 phone calls, and 4,000 messages of the client for the previous year, then, in order to evaluate credit risks, specialist will need a well-advised plan of data analysis. For a start, it is necessary to contact own specialists with the task of study of consumer behavior, which usually work is sales or marketing department. For example, experienced expert in retail can point out the fact that consumer with limited income buys gas in small amounts and for round sum, while the one who doesn't care how much they pay for gas buy more and do not strive for round sum. In the same way, people who but gas on holidays, when prices are higher that usually, spend more as compared to those that strive to save and buy gas on holiday eve. When comparing two consumers with similar income, then the one who's inclined to saving model of behavior will be a preferred candidate for a loan.

Closer cooperation between specialists in risk evaluation and marketing department can lead company into new segments of consumers. While traditional approach of marketing specialists supposes that they choose targeted groups and contact specialists for evaluation of risks with the request to develop appropriate models, now these specialists can show to marketing specialists new sources of data which will help them to build contact with segments that haven't been among the list of top-priority ones.

Credit risk of retail bank products should be viewed as probability of losses due to influence of external and internal factors, as feedback reaction to managerial decisions, related to crediting of individuals. At that, losses in case of implementation of credit risk are individual's non-payment (full or partial) of principal of loan and loan interest. Thus, it is possible to distinguish four levels in hierarchical structure of credit risk of retail banking products:

1) level of borrower, where risks are directly determined by behavior of borrower who violates the terms of credit agreement;

2) individual level, where risks are caused by unlawful or incompetent decisions of credit office employees;

3) micro-level, where risks are caused by decisions of credit committee of the bank;

4) macro-level, where risks are pre-determined by external - as to the bank - macro-economic and legal terms of work.

At that, the levels borrower and macro-level include external factors as to the bank which cause the risk, while individual level and micro-level, on the contrary, include internal factors (Skrypnik, 2010). 
In reality, financial model should provide the algorithm of conduct of various alternative schemes of uncertain situations, related to strategic decision making and represent in practice a certain tool which allows viewing a large number of variants in the offered scenario. Selection of specific borrower from potentially possible ones is the main task during the formation of bank credit portfolio. Existing mechanisms of evaluation of creditability risks use various forms and schemes, groups of methodologies of expert evaluations. Experience of the recent 2008 crisis showed inconsistency of such methodologies, in particular, evaluation of real level of risk for clients: risks laid on banks appeared wider than it was expected due to accumulation, which posed a threat to functioning of national banking system on the whole. Depending on the sphere of emergence, risks are divided into two groups - internal and external, each of which, in its turn, depends on the list of clients, level of risk distribution, and nature of accounting of bank operation. In order to determine the value of financial risk, it is necessary to know all possible consequences of any particular action and probability of these consequences. Probability means the possibility of receiving certain result. For evaluation of the results of the researched groups, the risk coefficient is used which is calculated in the following way: numerator - total sum of losses, denominator - amount of own funds of the bank (Bespalov, Yashin, 2014).

Existing models of evaluation and forecast of credit risk are shown in Table 1.

Table 1. Types of models of evaluation and forecast of credit risk (Ivantsov, 2009)

\begin{tabular}{|l|l|l|}
\hline Statistical & Hybrid & Expert \\
\hline $\begin{array}{l}\text { Based on recognized interconnections between } \\
\text { common factors of risk emergence and evaluations } \\
\text { of risk parameters. Such models require large } \\
\text { volumes and high quality of gathered statistics }\end{array}$ & $\begin{array}{l}\text { Combine statistical } \\
\text { methods and expert } \\
\text { opinions }\end{array}$ & $\begin{array}{l}\text { Based on quantitative evaluations, conducted by } \\
\text { experts. These models are used for portfolios, in } \\
\text { which factors of risk emergence are not } \\
\text { expressed in quantitative form or there is too little } \\
\text { data (portfolios with low quantity of defaults) }\end{array}$ \\
\hline
\end{tabular}

At the same time, all these models of evaluation of credit risk - statistical, hybrid, and expert - are based on mathematical calculations. That's why we offer to use for evaluation of risks of consumer crediting and their forecast logical and/or expert mathematical models and requirements of Basel-2 in part of mandatory calculation of default probability and effectiveness of risks levying. Formation and perfection of any of these models require creation of algorithm of making decisions regarding the level of riskiness of operations of consumer crediting for its separate directions (Sokolinskaya, 2011).

Organization of the system of management of retail credit risks should be based on common principles of managing risks and requirements and recommendations of regulating bodies.

Main principles of managing retail credit risks include:

1) Principle of abidance by the Russian law and existing requirements of the Central Bank of the RF. While conducting its activities, the bank strictly abides by the crediting norms set by the Central Bank of the RF, including formation of reserves for possible loan losses.

2) Integrity of principles. Principles of policy for management of retail credit risks are similar for all functional and structural departments of bank.

3) Principle of abidance by internal limits. Internal limits of bank in part of retail credit risks do not contradict existing laws on banks and are aimed at specification of criteria of credit decisions making.

4) Principle of monitoring of retail credit portfolio. Bank performs obligatory periodical monitoring of retail credit risks at the level of credit portfolio; at that, portfolios - for the aims of analysis - are aggregated as to criteria of essentiality.

5) Principle of integrity of the procedure of decision making and evaluation of deal risk. All credit decisions should be taken within the confirmed system of authorities and on the basis of all available information on borrower. Each deal supposes mandatory complex analysis of creditability of borrower, based on the evaluation of due diligence, evaluation of risk, and calculation of paying capacity. Under the condition of lack of repeated verifications of borrower by various departments of bank.

6) Principle of integrity of technological basis. Bank should pay attention to development of technologies of retail crediting for the purpose of provision of integrity of technological process of crediting, achievement of maximal level of automatization of credit decision making, registration and further accounting of given loans, and formation of reports.

7) Principle of storing and further analysis of information regarding borrower. Bank should provide storing of all received information regarding borrower, including results of internal checks and evaluations, and information 
regarding the process of credit issue, for further analysis, evaluation of effectiveness of the process of crediting, and improvement of algorithms of automatic decision making.

Banks have to seek the following goals in part of management of credit risks:

1) achievement of required (targeted) level of credit risk for retail credit portfolio, under the conditions of minimization of expenses for performance of activities;

2) optimization and diversification of credit risks for retail bank products;

3) implementation of single system of decision making for credit applications of retail bank.

Priorities of development of the system of management of retail credits risks are:

1) perfection and actualization of methodological basis of management of retail credit risks;

2) perfection of the system of distribution of authorities for decision making for products and credit applications of retail bank;

3) development of tools of management of retail credit risks and development of risk technologies, including algorithms of automatic decision making (scoring);

4) perfection of the system of accounting, which allows receiving information on the level of retail credit risks at all levels of management.

System of management of retail credit risks in the bank is shown in Fig. 2 and consists of the following interconnected elements: strategy of management of retail credit risks, process of management of retail credit risks, methodology of management of retail credit risks, technology of management of retail credit risks, and operational environment.

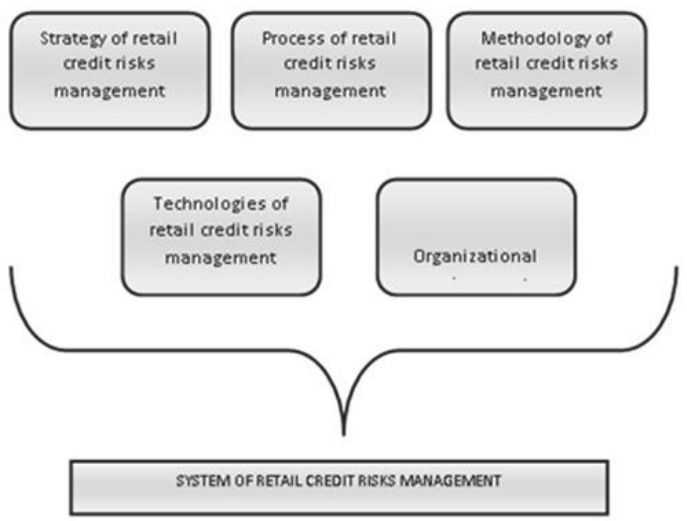

Figure 2. System of retail credit risks management

Strategy of retail credit risks management determines the goals of management of retail credit risks, principles of retail credit risks management, organizational model of authorities, and liabilities for retail credit risks management.

Process of retail credit risks management is a totality of actions, the successive performance of which provides achievement of the goals of the credit risks management system. The process of management of retail credit risks covers the deals of retail crediting and may cover the deals for small business crediting.

The process of management of retail credit risks is conducted on constant cyclical basis and includes the following stages:

Methodology of management of retail credit risks is a totality of developed internal bank documents which provide stability of implementation of the process of retail credit risks management.

Technologies of management of retail credit risks are the totality of technical and informational systems, data bases, and systems for automatic decision making, which provide reduction of labor intensity of implementation of the process of management of retail credit risks and increase of effectiveness of the use of methodology of retail credit risks management.

Organizational environment includes organizational departments of banks and bank employees which implement the process of retail credit risks management, organizational documentation of department, and elements of corporate culture of the bank which forms comprehensive attitude of bank employees to risk management that is shared by 
employees of all levels and functional directions.

All elements of the system of retail credit risks management should be integrated into the common system of bank management.

\section{Conclusions}

Thus, it is possible to conclude that, despite a large number of studies in the sphere of retail banking, active development of this direction of banking sector was accompanied by high risks and high level of competition in the market of banking services that led to necessity for constant search for actual and effective solutions in the sphere of organization and development of retail banking.

Constant interest to retail banking from banks and clients leads to the growth of volumes of crediting, which, certainly, is reflected in evolution of not only forms and methods of conduct and organization of banking business, but in evaluation of credit risks, related to issue of retail credits. With all diversity of methodologies, it is impossible to distinguish a perfect one. During evaluation of credit risks, banks have to orient, first of all, at bank's credit policy, scale, and specifics of branch network. Methodologies of evaluation of creditability of individual actively evolve in view of changing laws, development of informational technologies, and growing risks regarding active operations of banks. The conducted analysis allowed allocation evolution of methods which ensure improvement and preservation of quality of retail assets, which took place in recent years.

For banks, perspective directions are building long-term and high-quality relations with clients through improvement of the quality of provided services and individual approach which consists is selling not a specific product, but solution to client's problems, and development of innovational products and services.

\section{References}

Azriliyan, A.N. (2007). New economic dictionary. Institute of New Economy.

Bespalov, I.V., Yashin, N.M. (2014). Financial risk management model of the Russian banks. Modern problems of science and education, $2,442$.

Demidov, A., Goryunov, A., Rybkina E. (2004). How to build a retail bank. Banking technologies, 12.

Ivantsov, E. (2009). Lessons of Financial Crisis: Why Credit Models Fail. HSBC.

Institutional evaluation of the banking services market: monograph (2012). L.I. Chernikova, E.N. Egorova, V.M. Zaerniuk, G.R. Faizova; edited by L.I. Chernikoi. - M.: FGBOU VPO «RGUTiS», 206 p.

Egorova E. N. (2011) Fiscal monitoring as an information base tax regulation. Service plus. No. 1. P. 87-93.

Kardashov, V.V. (2007). The operating model of retail business development bank. Retail banking, 3.

Kocharyan, K.S. (2009). Improving the infrastructure of retail banking business. Transportation business in Russia, 9, 112-114.

Krestovskiy, I.A. (2010). Development of Retail Banking. Dissertation of the candidate of economic sciences.

Lukoyanova, E.A., Shibakov, V.G. (2011). Credit risk management in retail lending - a topical issue for the banking community. Socioeconomic and technical systems: Research, design, optimization, 3, 57-64.

Rubin, Y.B. (2007). The course is a professional business, 2, 94.

Semenyuta, O.G., Amichba, A.L. (2011). Theoretical basis of the research infrastructure of the banking market. Financial Research, 2, $34-40$.

Silaeva, A.A. (2012). Regulation of the social component of banking services at the present stage in Russia. Service in Russia and abroad, $7,40$.

Skrypnik, E.Y. (2010). Assessment of the credit risk of retail banking products at the stage of the loan. // Herald of the Voronezh State University. Series: Economics and Management, 2, 221-230.

Sokolinskaya, N.E. (2011). Models forecast risk retail portfolios. Financial Journal, 2. 95-104.

Trofimov, D.V. (2013). Improving the competitiveness of banks in the retail banking market of the Russian Federation. Management of economic systems: an electronic scientific journal, 10, 77.

Zaernyuk, V.M., Faizova, G.R. (2012). Prospects for the development of retail banking services in the Russian market. Finances and Credit, 38, 17-23.

Zaernyuk, V.M., Faizova, G.R. (2012). Combination products as a way to expand the product line commercial bank. Problems and experience in management, finance, accounting and taxation of enterprises, branches, complexes. Digest of articles, 153-160.

Zaernjuk, V. M., Kryukova, E. M., Bokareva, E. V., \& Chernikova, L. I. (2014). A study of the theoretical approaches to the banking financial intermediation and its development trends. World Applied Sciences Journal, 30, 1723-1725.

Faizova, G.R. (2013). Retail banking business: current state and specificity. Modern studies of social problems (electronic scientific journal), 3 .

Chernikova, L.I., Zaernjuk, V.M. (2011). Accessibility of banking services in the regions of Russia: problems and solutions. Service plus, $4,71-80$. 